\title{
An assessment of wildlife road casualties - the potential discrepancy between numbers counted and numbers killed
}

\author{
F. M. Slater
}

Slater, F. M. 2002. An assessment of wildlife road casualties - the potential discrepancy between numbers counted and numbers killed. - Web. Ecol. 3: 33-42.

\begin{abstract}
By artificially baiting roads, it is shown that simple counts of wildlife corpses found on roads are severe underestimate of the actual road casualty rate. The death rate can be $12-$ 16 times that observed by simply counting corpses particularly from a moving vehicle. Removal rates depend on a range of factors including species of predator, species of prey, type and topography of road, road traffic, season, time of day and weather conditions. It is suggested that a greater importance should be afforded, than has previously been the case to the "gross" casualty rate rather than accept the "net" number of casualties as an indicator of loss.
\end{abstract}

F. M. Slater(slaterfm@cf.ac.uk), School ofBiosciences, CardiffUniv., Llysdinam Field Centre, Newbridge-on-Wye, Powys, U.K. LD1 6NB.

Although the conservation movement has created islands of sanctuary for many species within formal and informal nature reserves, in a country such as Britain with a dense road network such protection does not always remove the threats from road, and to a lesser extent other forms of transport, to both vertebrates and invertebrates.

In contrast to "islands" of conservation, "islands of isolation" may in part be created due to habitat fragmentation by roads, and can threaten the large scale metapopulations of some species (Verboom and van Apeldoorn 1990, Harrison 1991, Bright 1993, Fahrig and Merriman 1994, Hastings and Harrison 1994, Hanski et al. 1994, Vos and Chardon 1998, Gerlach and Musolf 2000).

There are a considerable number of studies, reviewed by Slater (1994) and spanning more than a century, which have documented the qualitative relationships between vehicular traffic and wildlife, but most of these take scant account of injured animals dying away from the road and of the corpses which are scavenged before they are censused. The aim of this study, therefore, is not to produce a statistically definitive account of wildlife road casualties, but to flag up the problems inherent in the conventional counting approach to this problem. As Forman and Hersperger (1996) point out "the ecological literature on the subject is embryonic and scattered," with only a few recent synthetic studies e.g. Langton (1989), Reck and Kaule (1993), Reijnen (1995), Reijnen and Foppen (1995), Clarke et al. (1998), Trombulak and Frissell (2000). The problem is investigated by answering these main questions: 1) How many wildlife road casualties are found using conventional census techniques? 2) To what extent do the numbers found by conventional census techniques represent actual numbers killed? 3) What are the variables influencing the rate of removal of corpses from roads? 


\section{How many road casualties are found using conventional census techniques?}

\section{Methods}

The number of road casualties observed on a $68 \mathrm{~km}$ circuit of roads of varying classification in mid-Wales were recorded from dawn onwards twice weekly for one year. The whole circuit was covered by car but four contrasting $2 \mathrm{~km}$ lengths were also on 20 occasions coinciding with car survey to compare the relative efficiency of vehicle versus onfoot records. Data were also collected on a casual basis to obtain a more comprehensive picture of the number and range of species getting killed on the roads. The car survey was undertaken by a driver and observer and the four $2 \mathrm{~km}$ lengths were walked by other staff.

\section{Results}

The results of the circuit data are shown in Tables $1 \mathrm{a}, \mathrm{b}$ and 2 and Fig. 1. Figure 1 shows the spatial distribution of the road casualties from the vehicle survey and these are expressed in percentages in Table 2. It is apparent that the percent of casualties per road class is not dissimilar to the percent of the circuit accounted for by that road type. What is clear is that the worst blackspots for casualties are on A roads, the two worst spots being associated with the village of Newbridge-on-Wye and a recently improved and reseeded road junction. Only the $\mathrm{C}$ roads had sections from which no road casualties were found. Table 3 clearly shows that a survey conducted on foot was far more efficient at recording road deaths, in particular small animals such as bats and the scant remains of very flattened amphibians.

Counts were made soon after dawn based on the premises that: a) Most road casualties occur between dusk and a couple of hours after dawn. b) Scavengers will be most active in the early post-dawn period. Although there were clear qualitative differences in the animals killed between seasons e.g. young birds killed in summer, the seasonality of migrants, spring migration of amphibians, and in the annual variations in traffic flow (Table 4) these variables were not taken further.

\section{Observations}

Although it is clear that searching on foot is more effective than a "drive-by" count, the differences are accentuated by a few occasions in spring when the remains of very degraded amphibian corpses were visible only on close inspection. The class of road seemed to have some effect on
Table 1a. Number of non-bird fatalities in this study.

\begin{tabular}{llr}
\hline Species name & Scientific name & No. \\
\hline Hedgehog & Erinaceus europaeus & 72 \\
Pipistrelle & Pipistrellus pipistrellus & 1 \\
Rabbit & Oryctolagus cuniculatus & 54 \\
Brown hare & Lepus capensis & 5 \\
Grey squirrel & Sciurus carolinensis & 32 \\
Brown rat & Rattus norvegicus & 4 \\
Red fox & Vulpes vulpes & 1 \\
Badger & Meles meles & 3 \\
Stoat & Mustela erminea & 1 \\
Polecat & Putorius putorius & 3 \\
Otter & Lutra lutra & 1 \\
Domestic cat & Felix domestica & 2 \\
Sheep & Ovis & 1 \\
Common toad & Bufo bufo & 12 \\
Common frog & Rana temporaria & 5 \\
\hline
\end{tabular}

Table 1b. Number of bird road casualties in this study.

\begin{tabular}{llc}
\hline Species name & Scientific name & No. of birds \\
\hline Buzzard & Buteo buteo & 1 \\
Pheasant & Phasianus colchicus & 1 \\
Black-headed gull & Larus ridibundus & 1 \\
Woodpigeon & Columba palumbus & 5 \\
Tawny owl & Strix aluco & 5 \\
Skylark & Alauda arvensis & 3 \\
Swallow & Hirundo rustica & 2 \\
Carrion crow & Corvus corone & 17 \\
Jackdaw & Corvus monedula & 1 \\
Magpie & Pica pica & 5 \\
Blue tit & Parus caeruleus & 6 \\
Wren & Troglodytes troglodytes & 2 \\
Mistle thrush & Turdus viscivorus & 2 \\
Song thrush & Turdus philomelos & 5 \\
Redwing & Turdus musicus & 1 \\
Blackbird & Turdus illiacus & 51 \\
Robin & Erithacus rubecula & 11 \\
Garden warbler & Sylvia borin & 1 \\
Whitethroat & Sylvia communis & 1 \\
Willow warbler & Phylloscopus trochilus & 3 \\
Dunnock & Prunella modularis & 3 \\
Meadow pipit & Anthus pratensis & 3 \\
Greenfinch & Carduelis chloris & 2 \\
Goldfinch & Carduelis carduelis & 1 \\
Chaffinch & Fringilla coelebs & 8 \\
House sparrow & Passer domesticus & 12 \\
Great spotted woodpecker & Dendrocopos major & 1 \\
Green woodpecker & Picus viridis & 1 \\
& & \\
& &
\end{tabular}




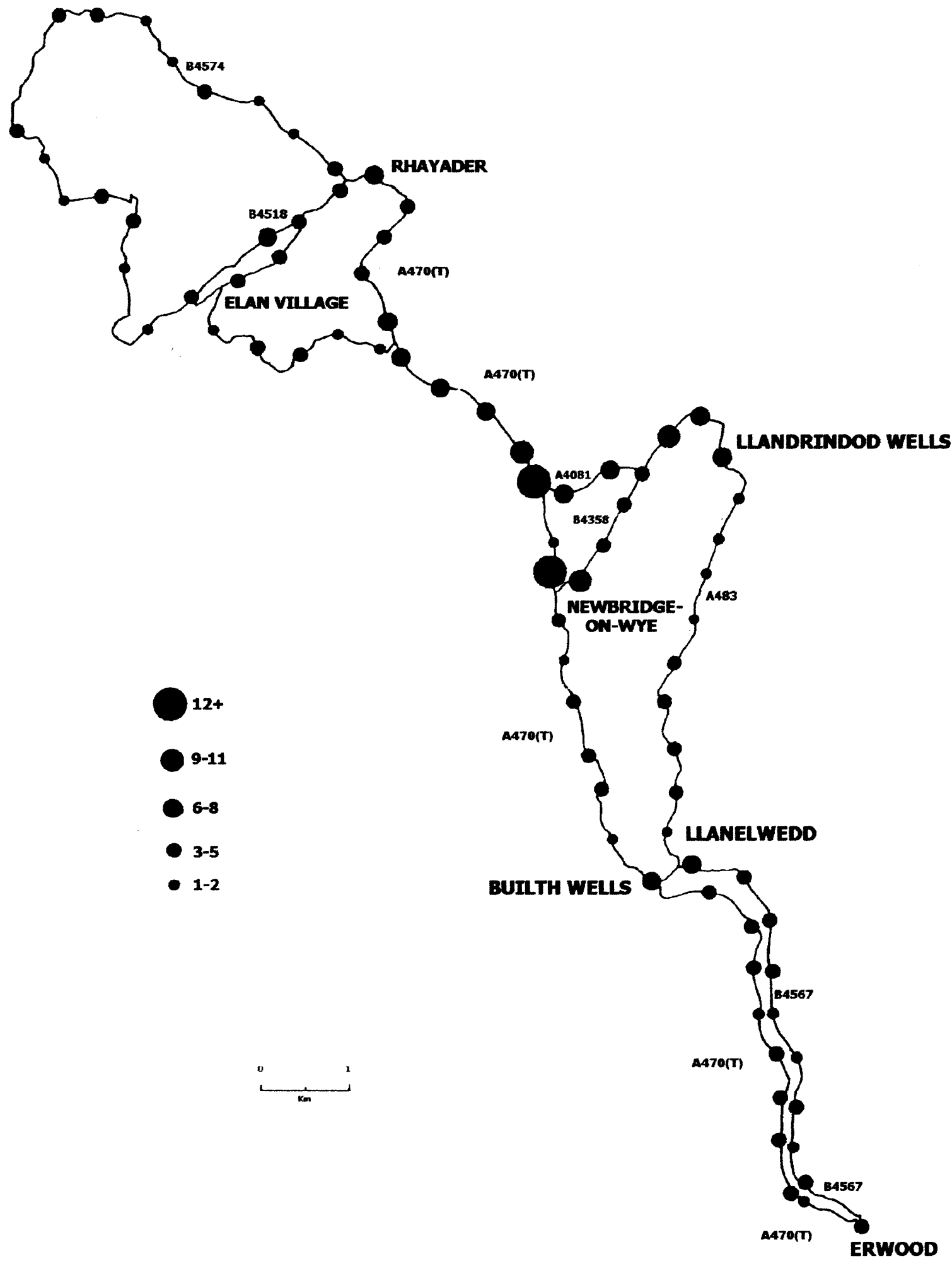

Fig. 1. Map showing the road circuit surveyed and total casualties recorded per section. The A470 follows the course of the River Wye, the altitude at Erwood is $120 \mathrm{~m}$ and at the extreme northern point of the circuit is $488 \mathrm{~m}$ on the hills above Rhayader. 
Table 2. Percentage of total road casualties expressed by road classification.

\begin{tabular}{lccc}
\hline Road classification & A & B & C \\
\hline \% of circuit & 52 & 20 & 17 \\
\% of casualties & 51 & 29 & 20 \\
\hline No. of casualties km ${ }^{-1}$. & A & B & C \\
& (\% sites with casualty no. $\left.\mathrm{km}^{-1}\right)$ \\
\hline 12 & 5 & 0 & 0 \\
$9-11$ & 2 & 4 & 0 \\
$6-8$ & 31 & 17 & 0 \\
$3-5$ & 38 & 50 & 59 \\
$1-2$ & 24 & 29 & 41 \\
0 & 0 & 0 & 24 \\
\hline
\end{tabular}

Table 3. Comparison of comparative counts of $4 \times 2 \mathrm{~km}$ stretches of road recorded from a vehicle and on foot. Values are total road casualties observed over the same 20 sampling occasions for car and on foot.

\begin{tabular}{lcc}
\hline $2 \mathrm{~km}$ & Car & On foot \\
\hline 1 & 6 & 37 \\
2 & 0 & 11 \\
3 & 4 & 29 \\
4 & 7 & 17 \\
\hline
\end{tabular}

the pattern of deaths but topography and land use are probably as important. Most deaths were found within a built up area and on a road junction newly planted with ryegrass Lolium perenne which attracted many rabbits and which had a well-used badger track crossing two "A" class roads. Fewest casualties were found on " $\mathrm{C}$ " class roads crossing upland, unfenced sheep walks.

From these results the pattern of wildlife road casualties begins to build up but is it anything other than a qualitative indication of the magnitude of the road death problem?

\section{To what extent do the numbers found by conventional census techniques represent actual numbers killed?}

This problem was approached by posing some supplementary questions: a) What is the natural fate of road casualty corpses? b) What variables influence removal rate?

\section{Methods}

a) To examine the natural fate of the bodies of wildlife road casualties a series of observational experiments were set up. A vehicle with observer was parked on one of several laybys on the A470 and bait (chicken head) was placed $50 \mathrm{~m}$ beyond the car on the edge of the road and the bait observed until it was removed (or $4 \mathrm{~h}$, whichever was the longer). The process was repeated in the next layby until 10 repetitions had been completed both day and night. For night time observations a Pocketscope image intensifier was used. Ten, $1 \mathrm{~m}^{2}$ sand trays with chicken head bait in the centre were placed at random sites along the verge of the A470 (B and C class roads usually had insufficient verge width) on one night per week for 5 weeks in May/June. The sand was smoothed prior to leaving and markings in the sand noted the following day. The entire $68 \mathrm{~km}$ circuit was travelled once per month throughout the year beginning at midnight and roadside scavengers noted.

b) To investigate the variables influencing removal rate several experiments were performed. Clearly, to investigate removal rates experimentally wildlife road casualties could not be used as bait therefore the first experiment was to determine which bait(s) had a similar attractiveness to natural road casualties. The selection was limited by availability and included small rodents (trap casualties), road casualty toads, rabbit, hare, grey squirrel, guinea pig, white mice (culled laboratory stock), day old chicks and chicken heads used whole, halved or halved and crushed with some

Table 4. Mean traffic flow per hour - July and January on A470(T) in mid Wales.

\begin{tabular}{lccccccccccccc}
\hline Month & 1 & 2 & 3 & 4 & 5 & 6 & 7 & 8 & 9 & 10 & 11 & 12 & \\
\hline July & $<10$ & $<10$ & $<10$ & $<10$ & $<10$ & 30 & 47 & 150 & 230 & 160 & 340 & 300 \\
Jan & $<10$ & $<10$ & $<10$ & $<10$ & $<10$ & 22 & 32 & 57 & 110 & 105 & 130 & 137 & \\
\hline Month & 13 & 14 & 15 & 16 & 17 & 18 & 19 & 20 & 21 & 22 & 23 & 24 & \\
\hline July & 282 & 345 & 345 & 366 & 398 & 321 & 247 & 192 & 131 & 84 & 54 & 30 & \\
Jan & 135 & 140 & 160 & 166 & 170 & 159 & 90 & 72 & 58 & 43 & 30 & 25 & \\
\hline
\end{tabular}

Based on Powys County Council data. 
samples stained with potassium permanganate to make their colour less obvious. The various baits were dropped in random order from a moving vehicle at ca $100 \mathrm{~m}$ intervals and their day retention time on the road recorded by repeated passes along the baited areas. Table 6 shows the ranked speed of removal for all the baits used.

Because data from Table 6 shows that halved crushed chicken heads were a highly ranked bait, these were then used in subsequent road baiting experiments except for the following. Rabbit and grey squirrels were cut into ca 25 , $50,100,150,200$ and $>500 \mathrm{~g}$ portions, retaining the fur. Ten portions of each weight were dropped during daytime in random order from a moving vehicle at ca $100 \mathrm{~m}$ intervals and their removal rate monitored by repeated passes along the baited area. The same experiment was repeated during the hours of darkness. The mean retention time for each sample weight is shown in Fig. 3.

To determine if the proximity of baits influenced their rate of removal, 20 baits were dropped from a moving car at each of 5 spacing intervals and the results recorded hourly. The experiment was repeated 3 times and the mean cumulative percentage removal is shown in Fig. 6 .

Baiting experiments were generally never conducted over the same circuit more than once per week to prevent the possibility of habituation of scavengers to the food source. However, to determine if this could be a problem, 50 baits were dropped at $100 \mathrm{~m}$ intervals on seerate circuits on three separate circuits on three separate days and a further 50 baits were dropped at $100 \mathrm{~m}$ intervals on the same circuit on three successive days and the removal rates noted as above (Figs 4, 5).

On a habituated circuit i.e. one regularly baited, the effect upon traffic density of removal rate was examined. Carion crows had begun to expect food on the stretch of road and would remove it almost as soon as it was dropped. Using three motorbikes to pass and re-pass the relatively short length of normally quiet $\mathrm{C}$ class road it was possible to simulate the passage of up to 700 evenly spaced vehicles per hour far more than use the main A470 in high summer (Table 4).

To determine when baits were removed during the diurnal cycle and to what extent weather influences removal, a different circuit was baited with 100 bait at $100 \mathrm{~m}$ intervals on each of three successive days in December and the remaining bait recorded throughout the night and the following day. On the first day there was thick fog, thinner fog on the second day and clear conditions on the third. This was regarded as a non-replicable experiment.

Towards the end of the experimental period the data shown in Fig. 1 was used in conjunction with verge width data to produce Fig. 2.

\section{Results}

The sand trays produced few results with just one set of fox footprints and three sets of cat footprints throughout the whole experiment. Visual observation found that carion crows were the most important remover of bait in the day and domestic cats were the only scavenger seen to remove baits at night. However observation of animals scavenging on the circuit at night found cats to far outrival all other animals even up to $2 \mathrm{~km}$ from the nearest human habitation, followed by badger, polecat, fox and hedgehog in that order. During the day only crows were seen at static sites although other corvids, blackbirds and buzzards were seen at corpses along circuits.

Table 6 shows the ranking of baits in terms of speed of removal from roads. Light coloured baits such as white mice and day old chicks were removed quickly but less so when stained. Similarly unstained chicken heads went more quickly than stained material. Heavy bait (above 150
Fig. 2. Graph showing the relationship between verge width (m) and the totalled number of casualties for the whole survey, standardised for unit length.
Regression of verge width against number of casualties

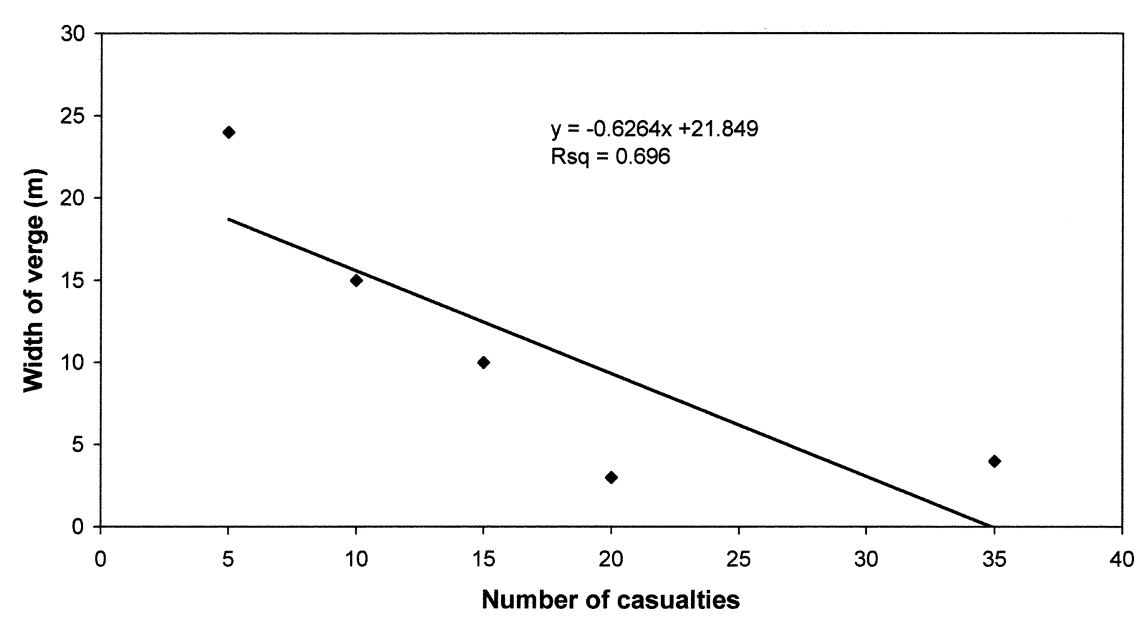




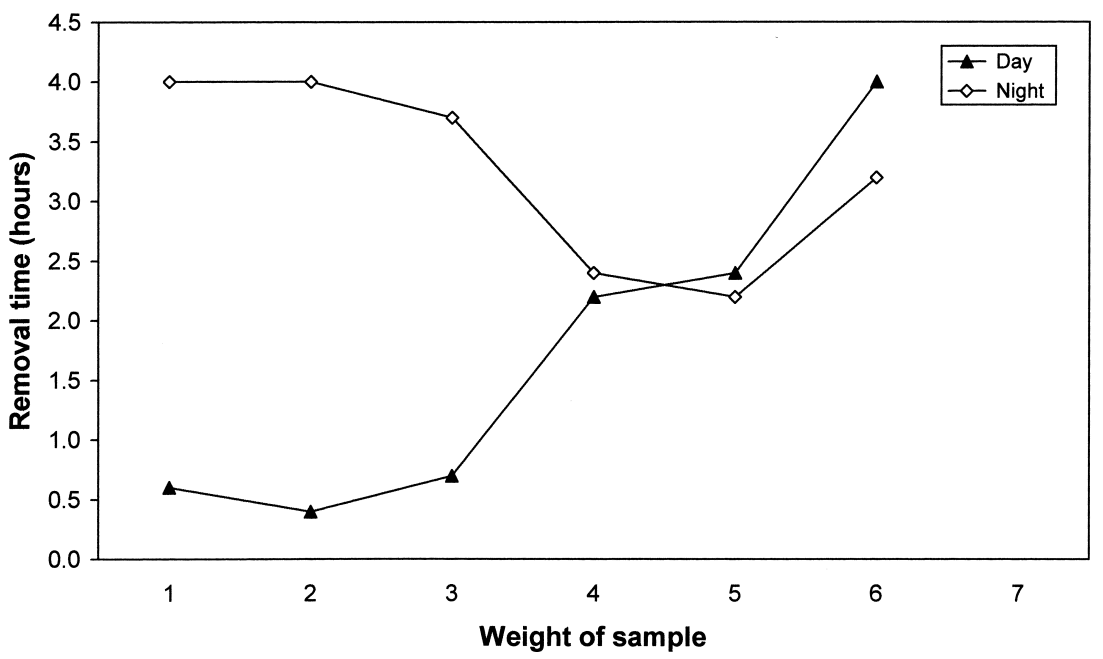

Fig. 3. Graph showing the mean time $(n=10)$ for bait of different weights to be removed from roads by day and night.

(NB: $\mathrm{x}$-axis: $1=25 \mathrm{~g} ; 2=50 \mathrm{~g}$; $3=100 \mathrm{~g} ; 4=150 \mathrm{~g} ; 5=200 \mathrm{~g}$; $6=500 \mathrm{~g})$.

g) was removed the slowest and even then the body was simply moved to the side of the road for later consumption. Because of their acceptability and availability halved crushed chicken heads were the main bait used in subsequent experiments.

The larger bodies of rabbit and grey squirrel were cut into portions of different weight and their removal rate noted. As most of the daytime scavengers were crows items over about $150 \mathrm{~g}$ were not carried away from the road, but at night even larger pieces were completely removed by other scavengers.

The effect of bait spacing shown in Fig. 4 showed that the residence time on the road of individual baits placed at
$0.1 \mathrm{~km}$ intervals was approximately half that of baits placed at $0.8 \mathrm{~km}$ intervals and that distances intermediate between these two had intermediate residence times.

Approaching the problem of bait frequently from a slightly different point of view. Figures 5 and 6 show the effect of habituation on removal rate. Using 3 circuits the removal rate follows generally the same pattern but on the circuit used on three successive days removal rates are much faster on days 2 and 3 suggesting the scavengers are "expecting" the bait.

When traffic rates of up to 700 vehicles per hour were simulated the rate of removal of bait was not impeded by the flow. As Table 4 shows lower maximum hourly flows,

\section{Cumulative \% Removal of Baits at Different Spacing}

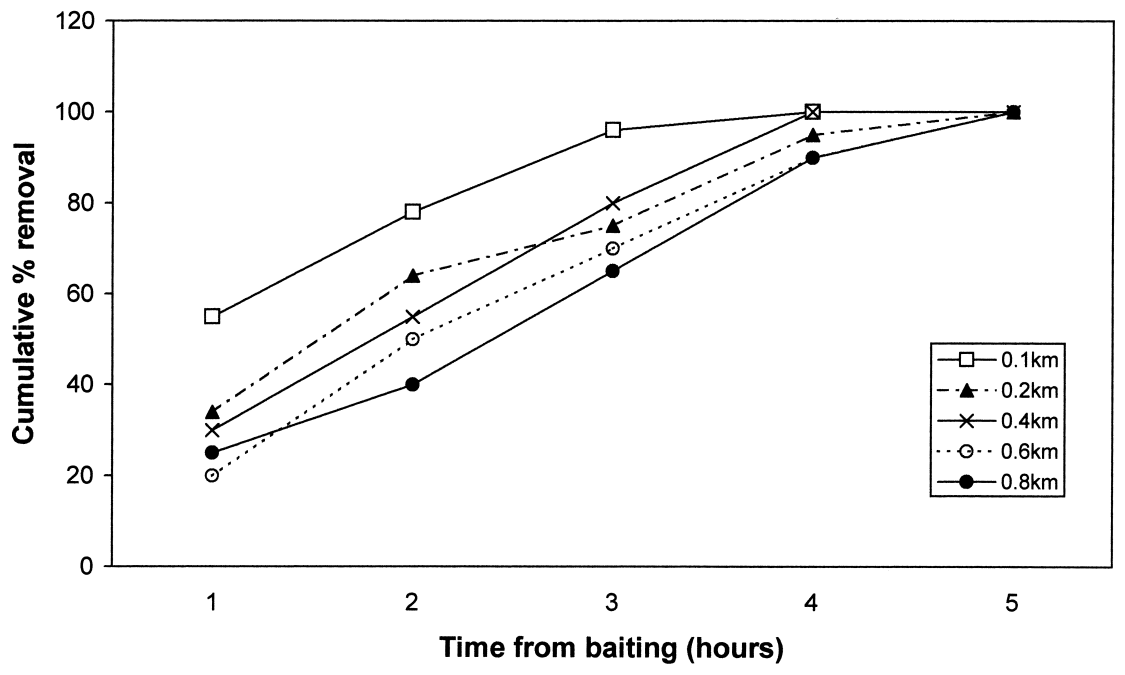

Fig. 4. Graph showing the effect of spacing between baits on rate of removal. Each line is the mean of at least 3 repetitions. 
Fig. 5. Graph showing the effect of repeated baiting on the same road over a $3 \mathrm{~d}$ period related to removal rate.

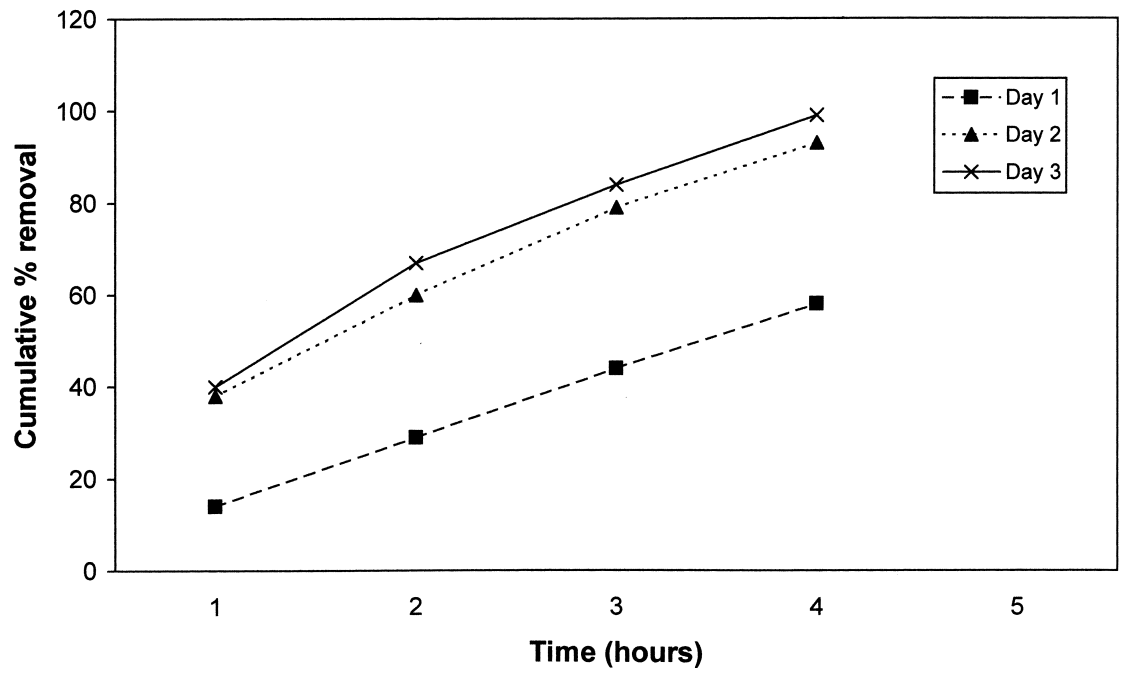

the rate of removal on these roads would not appear to be traffic flow dependent. Table 5 was devised as a replicated experiment using the three successive days in early December as the replicates. However, each day was markedly different from the next with thick fog, fog and clear conditions respectively and it was decided to include these data to illustrate the influence of weather on removal rates. In poor visibility few baits are removed whereas in clear conditions removal rates are much higher. Most of the A roads have significant verges and from Fig. 2 it can be seen that wider verges have fewer associated road casualties than narrow verges.

\section{Discussion}

\section{Scavengers}

Animals are found in the vicinity of roads for a number of reasons. Many scavenge the road surface for food: fox, cat, badger, mustelids and corvids for road casualties (Howes 1977) and hedgehogs mainly for invertebrates (Morris 1998), although they were also seen to eat chicken heads. Indeed invertebrates themselves may be scavengers for Pickles (1942) noted that the ant, Myrmica ruginodis, scavenged traffic-killed insects in Yorkshire and for others the

\section{Cumulative \% Removal on 3 Circuits Used Once}

Fig. 6. Graph showing removal rate with time on 3 circuits used once only.

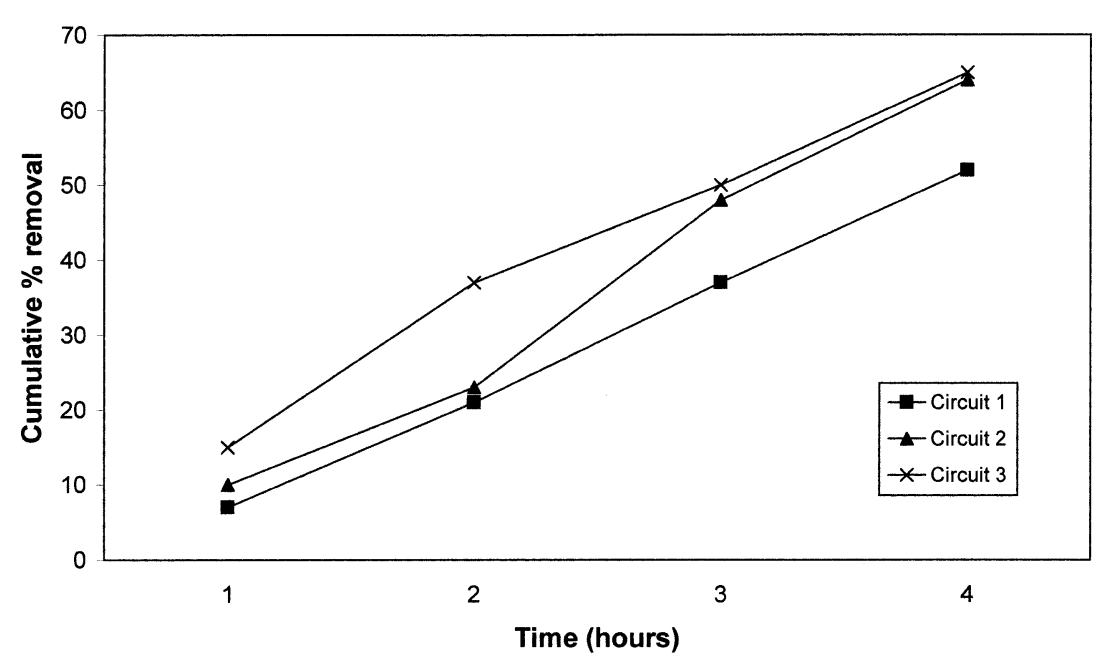


Table 5. Diurnal bait removed dusk to dusk over 3 successive days in December.

\begin{tabular}{lccccccrrr}
\hline & \multicolumn{9}{c}{ \% of bait remaining } \\
Date & $16: 30$ & $20: 00$ & $23: 00$ & $02: 00$ & $05: 00$ & $08: 00$ & $11: 00$ & $14: 00$ & $16: 00$ \\
\hline 8 Dec. & 100 & 92 & 87 & 84 & 82 & 51 & 32 & 18 & 12 \\
9 Dec. & 100 & 85 & 78 & 76 & 74 & 28 & 18 & 14 & 9 \\
10 Dec. & 100 & 79 & 67 & 67 & 67 & 25 & 7 & 0 & 0 \\
\hline
\end{tabular}

verges themselves have conservation value (Eversham and Telfer 1994). Hodson (1962) notes a covey of partridge taking grit from a road surface; water for drinking, mud for nests and dust for bathing may also induce birds on to a road surface. Finnis (1960) notes an observation of the late James Fisher that rooks (and sometimes pheasants) alight on roads on dewy mornings apparently to keep their feet dry. Roadside hedges are used for nesting, roosting (Woodward 1960) and feeding, and roads frequently bisect habitat so that juvenile birds may need to cross from nesting to feeding sites or amphibians from hibernation to breeding areas (Slater et al. 1985). Roads may simply cross a bird's flight path (Foppen and Reijnen 1994), or birds such as owls may swoop towards vehicle lights (Hodson 1962) where they may be temporarily blinded by the bright lights (Labisky 1959). Indeed it is not just the road but its zone of effect which needs to be considered (Forman 2000). Therefore, for whatever reason, animals venturing onto roads become potential road casualties. The results from the circuit data suggest that only one road casualty occurs per day for every $30 \mathrm{~km}$, results which from the experimental data would seem to be a considerable underestimate. It is clear from Table 2 that road type affects the number of casualty blackspots but the proportion of casualties was approximately proportional to the amount of that road class in the circuit. Low casualty numbers on unclassified roads reflect the lower speeds and low traffic volumes as well as the low predator densities on the upland moors where sheep are the most frequent casualties. Illner (1992) demonstrated the influence of road type on population levels of Westphalian owls. The list of casualties covers most of the commoner species seen on the roads although a frequent road feeder such as the pied wagtail was not reported as a road victim, probably by virtue of its alert feeding regime. Experience would seem to be important as many road casualty blackbirds, grey squirrels and rabbits would seem to be from road-traffic-inexperienced young of the year.

From general observations and Table 5 the maximum removal rate was observed one hour before to two hours after dawn with another peak just after dusk. The top ranked baits in Table 6 had a mean retention time of 31 min and this does not seem to be influenced by traffic density at the levels experienced on mid-Wales roads. During daylight hours, after the corvids, cats were observed to be occasional scavengers; a blackbird was seen to take a cardamaged slow-worm; a blue tit was seen to enter the decayed rib cage of a long dead road casualty sheep to feed on fat and a stoat was seen during daylight to remove an injured juvenile rabbit. With corvids it was found that scavenging rate was less related to initial bait density than the frequency with which they were allowed to remove prey from the same site. To prevent habituation, any one stretch of road was not used more frequently than once in three days.

Table 6. Ranked removal rate for baits used $(1=$ most rapidly removed - all expts).

\begin{tabular}{lll}
\hline Bait & Stained* & Unstained \\
\hline Chicken heads whole & 4 & 3 \\
Chicken heads half & 4 & 3 \\
Chicken heads half and crushed & 2 & 1 \\
Day old chicks & 2 & 1 \\
Small rodents (voles/woodmice) & N/A & 2 \\
White mice & 2 & 1 \\
Toads (road casualties) & N/A & 3 \\
Rabbit/hare/guinea pig/grey squirrel & N/A & 5 \\
\hline
\end{tabular}

*Stained with potassium permanganate. 


\section{Patterns}

Spatial, diurnal and seasonal patterns are readily observed in the casualty data. At a major "A" road junction which had been extensively seeded with Lolium perenne, a preferred grass species as food for the rabbit (Soan pers. comm.), this may have encouraged rabbits to feed there preferentially to inferior local pasture so exposing them to the risk of road mortality (Fig. 1). In the decade since the original observation was made, Lolium has been replaced by rank natural vegetation and although rabbits are still numerous nearby, daily observation over the last two years has recorded no rabbit deaths and only one badger death at this junction. Grey squirrel deaths were most frequent, perhaps not unexpectedly, on tree-fringed roads; elevated roads or roads with a verge width in excess of $10 \mathrm{~m}$ (Fig. 2) had fewer casualties than closely hedged or sunken roads or roads running along the base of a steep hill. There was a predictable seasonal element evident in bird casualties. Redwings, a winter visitor, had highest casualty rates in February, summer-visiting willow warblers and whitethroats in May and a May to August peak for nesting and newly fledged blackbirds. Dunthorn and Errington (1964) found that 3-30\% of fledglings of various bird species reared within $100 \mathrm{~m}$ of the road became road casualties. Seasonality has also been noted in the road casualty rates of badgers (Page et al. 1994) and otters (Philcox et al. 1999).

Diurnal activity patterns of both man and wildlife influence mortality patterns. Nighttime traffic flows in this rural area are only ca $5 \%$ of the daily total. As most of our larger mammals are predominantly crepuscular or nocturnal, they avoid the heaviest traffic flows but are particularly vulnerable in narrow lanes with steep banks where escape is difficult. On several occasions local topography and the location of the corpse suggested that badgers may have been deliberately run over, and in an associated study on migrating toads, signs warning of the migratory crossing encouraged some drivers to deliberately kill the toads with their cars (Slater 1994).

The collection of road casualty data using a vehicular censusing technique was used because of constraints on time and manpower even though it was subsequently demonstrated that searching on foot was far more productive. Indeed Beadnell (1937) noted the advantage of collecting data using a bicycle rather than a car. It rapidly became clear that vehicular censusing was not an acceptable quantitative method determining numbers of creatures killed, for not only will some animals be thrown off the road in a collision and others move off the road before they die, but corpses will also be removed by scavengers (Edwards and Slater 1981). In this study corvids were the main diurnal scavengers to be replaced at night mainly by domestic cats, polecats and foxes together with hedgehogs and badgers. Nearly half the road casualty badgers examined between 1986 and 1998 had presumed scavenged corpses (usually passerine remains) in their stomachs (unpubl.). There was less corvid scavenging on roads in spring when there are pickings from the supplementary feeding of sheep and from lambing fields, although the increasing use of indoor lambing facilities has reduced this food source. In the day, in the vicinity of buildings, cats rather than corvids are the major scavengers. The retention time of corpses on roads may not be more than a few minutes even with quite heavy traffic, although corpses larger than ca $150 \mathrm{~g}$ which, in general are not physically removed from the vicinity of the road (Fig. 3), may remain for several days and the spiny skins of hedgehogs remain long after the flesh has been removed. Scott (1938) noted that in Iowa, few corpses remain recognisable on roads after four days, over $60 \mathrm{yr}$ later, retention times are likely to be much less.

Birds are most active at dawn when again traffic density is generally just starting to increase. It is suggested that some birds that collect grit off roads in the early morning may be particularly vulnerable as are owls dazzled on the road at night.

Weather can influence road casualty data in two ways. Poor visibility can reduce removal rates and wet conditions both in the breeding season and throughout the summer can bring common toads on to roads to feed on the similarly responding earthworms and gastropods (Slater 1992) and this increased carnage can in turn result in more scavengers such as hedgehogs and badgers.

\section{Underestimating casualties}

A single daily corpse census probably underestimates daytime death rates by a factor of $12-16$ (i.e. retention time $\times$ hours of daylight). A Common Bird Census on 60 ha of farmland at Newbridge-on-Wye with ca $1 \mathrm{~km}$ of road, showed there is 26 and 14 nesting pairs of blackbirds and robins respectively, possibly producing ca 80 and 50 fledglings per year. Census data from the $1 \mathrm{~km}$ of road showed no deaths of either species. Clearly as observed mortality does not represent actual mortality, then, if corpse retention time in daylight, as discussed above, is about one hour then the actual mortality of fledglings of these species in these areas could be $10-15 \%$. With such a short retention time and $12-16 \mathrm{~h}$ of daylight in summer, the death rate could be 12-16 times greater than a single census would record. 178 common toad corpses were observed to be scavenged from the road surface around Llandrindod Wells lake in mid-Wales in one morning within an hour of dawn. No evidence of the road kill would have been found by a 10 am survey.

Whilst it is true that in recent years tunnels have been constructed under roads for toads badgers and deer (Langton 1989); "butterfly bridges" over roads have been built, ramps have been put into canals to rescue wildlife (Bekker et al. 1994) and wildlife considerations are more to the fore 
than in the past in development plans (Muller 1994) it is also true that, as the number of roads and the amount of road traffic continue to increase, it becomes increasingly necessary to be aware of the actual extent of the wildlife road casualties on our roads and by awareness seek further ways of alleviating the problem. It is suggested that the concept of a "gross" road casualty figures should be employed rather than the "net" casualty rate which single counts provide.

Acknowledgements - I acknowledge the Llysdinam Trust and the many students who have collected data for this project over several years.

\section{References}

Beadnell, C. M. 1937. The toll of animal life exacted by modern civilisation. - Proc. Zool. Soc. Lond. 107: 173-182.

Bekker, G. J., Harwig, D. and Wolfel, H. 1994. Summary of Dutch and German paper translations ramps and mammals drowning in canals. - British Walterways. Environ. and Sci. Serv.

Bright, P. W. 1993. Habitat fragmentation - problems and predictions for British mammals. -Mammal. Rev. 23: 101-111.

Clarke, G. P., White, P. C. L. and Harris, S. 1998. Effects of roads on badger Meles meles population in south-west England. Biol. Conserv. 86: 117-124.

Dunthorn, A. A. and Errington, F. P. 1964. Casualties among birds along a selected road in Wiltshire. - Bird Study 11: 168-182.

Edwards, R. W. and Slater, F. M. 1981. Impact of road deaths on wildlife conservation. - Nature in Wales 17: 153-156.

Eversham, B. C. and Telfer, M. F. 1994. Conservation value of roadside verges for stenotopic heathland Carabidae: corridors or refugia? - Biodiv. Conserv. 3: 538-545.

Fahrig, L. and Merrimam, G. 1994. Conservation of fragmented populations. - Conserv. Biol. 8: 50-59

Finnis, R. G. 1960. Road casualties among birds. - Bird Study 7: 21-32.

Foppen, R. and Reijnen, R. 1994. The effect of car traffic on breeding bird populations in woodland: 2 . Breeding dispersal of male willow warblers Phylloscopus trochilus in relation to the proximity of a highway. - Appl. Ecol. 31: 95-101.

Forman, R. T. T. 2000. The ecological road-effect zone of a Massachusetts USA suburban highway. - Conserv. Biol. 14: 3646.

Forman, R. T. T. and Hersperger, A. M. 1996. Road ecology and road density in different landscapes, with international planning and landscape solutions. - In: Evink, G. L. et al. (eds), Trends in addressing transportation related wildlife mortality. Harvard Univ., Cambridge, USA, pp. 1-24.

Gerlach, G. and Musolf, K. 2000. Fragmentation of landscape as a cause for gentic subdivision in bank voles. - Conserv. Biol. 14: 1066-1074.

Hanski, I., Henttonen, H. and Hansson, L. 1994. Temporal variability and geographical patterns in the population-density of microtine rodents. - A reply. - Am. Nat. 144: 329-342.

Harrison, S. 1991. Local extinction in a metapopulation context: an empirical evaluation. - Biol. J. Linn. Soc. 42: 73-88.

Hastings, A. and Harrison, S. 1994. Metapopulation dynamics and genetics. - Annu. Rev. Ecol. Syst. 25: 167-188.
Hodson, N. L. 1962. Some notes on the causes of bird road casualties. - Bird Study 9: 168-173.

Howes, C. A. 1977. A survey of the food habits of stoats Mustela erminea and weasels Mustela nivalis. - Yorkshire Nat. 102: $117-121$.

Illner, H. 1992. Road deaths of Westphalian owls: methodological problems, influence of road type and possible effects on population levels. - In: Glabraith, C. A. et al. (eds), The ecology and conservation of European Owls. JNCCP, pp. 94-110.

Labisky, R. F. 1959. Night lighting: a technique for capturing birds and mammals. - Biol. Not., No. 40, Nat. Hist. Surv. Div., Dept of Registration and Education, State of Illinois.

Langton, T. E. S. 1989. Amphibians and roads. - ACO Polymers, Sheffield.

Morris, P. A. 1998. Hedgehog rehabilitation in perspective. - Vet. Rec. 143: 633-636.

Muller, S. 1994. Wildlife Crossings. - Naturopa 76: 27.

Page, R. J. C., Ross, J. and Langton, S. D. 1994. Seasonality of reproduction in the European badger Meles meles in southwest England. - J. Zool. 233: 69-91.

Philcox, C. K., Grogan, A. L. and Macdonald, D.W. 1999. Patterns of otter Lutra lutra road mortality in Britain. - J. Appl. Ecol. 36: 748-762.

Pickles, W. 1942. Animal mortality on three miles of Yorkshire roads. - J. Anim. Ecol. 11: 37-43.

Reck, H. and Kaule, G. 1993. Strassen und Lebensraume: Ermittlung und Beurteilung strassenbedingter Auswirkungen auf Pflanzen, Tiere und ihre Lebensranume. - Forschung Strassenbau und Strassenverkehrstechnik, Heft 654, Herausgegeben vom Bundesminster fur Verkehr, Bonn-Bad Godesberg, Germany.

Reijnen, R. 1995. Disturbance by car traffic as a threat to breeding birds in the Netherlands. - Ph.D. thesis, Wageningen, The Netherlands.

Reijnen, R. and Foppen, R. 1994. The effect of car traffic on breeding bird populations in woodland: Evidence of reduced habitat quality for willow warblers Phylloscopus trochilus breeding close to a highway. - Appl. Ecol. 31: 85-94.

Reijnen, R. and Foppen, R. 1995. The effect of car traffic on breeding bird populations in woodland: 4 . Influence of poulation size on the reduction of density close to a highway. Appl. Ecol. 32: 481-491.

Scott, T. G. 1938. Wildlife mortality on Iowa highways. - Am. Midl. Nat. 20: 527-539.

Slater, F. M. 1992. The common toad. - Shire Publications.

Slater, F. M. 1994. Wildlife road casualties. - Brit. Wildl. 5: 214 222.

Slater, F. M., Gittins, S. P. and Harrison, J. D. 1985. The timing and duration of the breeding migration of the common toad Bufo bufo at Llandrindod Wells lake, mid-Wales. - Brit. J. Herpetol. 6: 424-426.

Trombulak, S. C. and Frissell, C. A. 2000. Review of ecological effects of roads on terrestrial and aquatic communities. Conserv. Biol. 14: 18-30.

Verboom, B. and van Apeldoorn, R. 1990. Effects of habitat fragmentation on the red squirrel Sciurus vulgaris. - Landscape Ecol. 4: 171-176.

Vos, C. C. and Chardon, J. P. 1998. Effects of habitat fragmentation and road density on the distribution pattern of the moor frog Rana arvalis. - J. Appl. Ecol. 35: 44-56.

Woodward, I. D. 1960. Notes on house sparrows. - Devon Birds 13: 23-25. 